\title{
Construction of Quality Evaluation System for Translation Majors in Application-Oriented Colleges and Universities
}

\begin{abstract}
QING Li-hua
South China Business College (SCBC), Guangdong University of Foreign Studies (GUFS), Guangdong, China

Under the background of “One Belt and One Road Initiative”, China’s internationalization improves greatly, which promotes all-round communication and cooperation between China and foreign countries; the demand for application-oriented translation talents is bound to increase substantially.Therefore, it is of great significance to establish a scientific and reasonable quality evaluation system to train translation professionals. This paper aims to discuss how to construct a quality evaluation system for translation majors in application-oriented colleges and universities for the purpose of promoting the translation talents cultivation.
\end{abstract}

Keywords: translation major, talents cultivation, evaluation system

\section{Introduction}

The outline of the National Plan for Medium-and Long-Term Education Reform and Development (2010-2020) clearly states: We will continue to optimize the structure of higher education, optimize the structure of disciplines, types, and levels, and promote interdisciplinary integration. It focuses on expanding the scale of application-oriented, interdisciplinary, and skilled personnel training. The mode of higher education in China has transformed from "elite education" to "mass education", and the development of application-oriented undergraduate education has become an inevitable trend in China's social development. As a application-oriented college, it is necessary to establish a scientific quality evaluation system for application-oriented talents by keeping with the times so as to enhance China's comparative advantages in this respect.

\section{Existing Problems}

Currently, the teaching quality evaluation standards for local applied undergraduate colleges and universities generally have the following problems.

Firstly, the local undergraduate colleges and universities evaluation should be application-oriented, but now their internal self-assessment usually refers to the qualified index system and assessment index system of

\footnotetext{
Acknowledgment: This research is financially supported by the province-level research project "English Language and Literature: A Key Program in Guangdong” (Project code: GDTX170109). It is also financially funded by the college-level research project "An Empirical Study on Innovative Strategies of Computer-aided Translation Technology in the Cultivation of Undergraduate Translation Talents”(Project code:2018SELC03).

QING Li-hua, MA., Associate Professor at South China Business College, Guangdong University of Foreign Studies, Guangdong, China.
} 
undergraduate course teaching from Ministry of Education; the indicators are commonly used in ordinary colleges and universities. Traditional training programs of translation talents only focus on language skills and translation practice ability without emphasizing its connection with the market and society, therefore, it is difficult for graduates to meet the requirements of work quickly. A challenge for such training program is to make sure that they prepare graduates for the needs of diverse professions in the rapidly changing market. This means that programs need to be developed with the market needs in mind and that they need to ensure a good match between graduates' competences and employer's requirements (Schaffner, 2012, pp. 37-45).

Secondly, the teaching quality evaluation system lacks the requirement of college-enterprise cooperation, and enterprises seldom participate in the teaching quality monitoring.

Thirdly, the evaluation content of teaching quality is not comprehensive enough; it often attaches importance to classroom teaching quality evaluation, neglecting extracurricular teaching activities evaluation. It emphasizes the evaluation of theoretical teaching, neglecting the evaluation of practical teaching. In addition, the implementation standards of practical teaching including experimental teaching, internship, practical training, graduation design are not strict and not flexible.

Fourthly, the evaluation subject and evaluation methods are relatively simple. The teaching quality evaluation subject is often colleges and universities which decide whether their teaching quality is good or bad, while enterprises seldom participate in teaching quality evaluation. They don't lay emphasis on the assessment of practical ability.

\section{Principles of Constructing Quality Evaluation Mechanism for Translation Majors in Application-Oriented Colleges and Universities}

\section{Pertinence Principle}

Local application-oriented undergraduate colleges and universities aim to cultivate application-oriented talents who meet the needs of industries and enterprises. Therefore, enterprises should be invited to participate in teaching quality management. The evaluation criteria should take into account the needs of enterprises for talents, so as to improve the quality of application-oriented translation talents training (Wang, 2018, pp. 143-146). Besides, based on the characteristics of application-oriented translation talents, the evaluation index should pay more attention to the practice part, highlighting the requirements for application-oriented scientific research, and improve the ratio of "double-qualified" teachers in the evaluation of teachers. Only in this way can application-oriented translation talents meet the demand of the market.

\section{Dynamic Principle}

The development of enterprises and industries is dynamic, so is the demand of enterprises and industries for talent specifications. Talent cultivation needs to be carried out in a dynamic environment. Therefore, the construction of teaching quality evaluation index system should reflect the openness and dynamics, which is conducive to promoting the diversification and specialization of college-enterprise cooperation.

\section{Operability Principle}

In the process of constructing talents cultivation quality evaluation index system for translation majors, it is necessary to fully consider that the object of the quality evaluation system of talent cultivation is applied to 
undergraduate colleges rather than research-oriented universities or vocational colleges, and the characteristics of locality, applicability and professionalism of applied undergraduate colleges should be concerned. Its design of evaluation index system should be operable.

\section{Construction of Quality Evaluation System for Translation Majors}

\section{Evaluation Subject}

The evaluation subjects of training quality for translation majors should be diversified, including colleges, enterprises, governments, graduates, and parents. College evaluation is the internal education system appraisal, which is applied to judge whether the talents have correct outlook on life and values, their foreign language proficiency, computer skills, physical and mental health, humanities knowledge, professional knowledge, and professional skills and so on. In terms of ideology and moral character, professional accomplishment and professional ability quality are considered. The enterprise mainly inspects the applied talents' professional morality quality, basic working ability, post development, and innovation ability from professional quality and professional ability. Graduates and their parents measure the education quality of application-oriented undergraduate colleges and universities mainly from the aspects of employment and entrepreneurship ability, students' satisfaction with colleges and universities and post-graduation salary (He \& Zhai, 2017, pp. 138-140). Only by taking the evaluation objects as the core and participating in the diversified evaluation subjects can the quality of talent cultivation be guaranteed.

\section{Evaluation Content}

Local applied undergraduate colleges and universities generally serve for local economy and construction. The applied undergraduate education and talent cultivation cannot simply adopt the academic talents cultivation mode adopted by comprehensive university and the single vocational skills training in vocational colleges. It should build talents quality cultivation system for the purpose of training application-oriented talents with knowledge, ability, quality, and objectives on the basis of the demand of the market. The evaluation contents of translation major in application-oriented undergraduate colleges should include teaching staff, teaching conditions and utilization, major and curriculum construction, quality management, practical teaching, study atmosphere construction and student guidance, and teaching quality.

\section{Evaluation Method}

The selection of evaluation methods should meet the requirements of content in the evaluation index system for talent cultivation quality, fully consider serving the evaluation objectives, and make the evaluation results objectively reflect the actual quality level of application-oriented talent training.

Comprehensive evaluation of college-enterprise cooperation. Outline of National Medium-and Long-Term Program for Education Reform and Development (2010-2020) points out that through collaborative innovation system the realization of cooperative education is a problem that needs to be solved from the concept, system, and mechanism of education at present and in the future. College-enterprise cooperation is the most mature collaborative cultivation mode, whose characteristic lies in the conjunction between the knowledge and talent resources in colleges and universities and the advantages of the business acumen to the market and capital operation in the enterprises. This mode can make full use of the resources of college sand enterprises and closely 
integrate the process of talents cultivation with the enterprise, which is beneficial to realize "seamless docking" between the talents training and social needs (Wu, Liang, Li, \& Wang, 2016, pp. 52-58).

Translation major is a highly practical one, and the quality evaluation of its talent cultivation should not only be evaluated by colleges and universities, but also by enterprises. The participation process consists of three levels: input, process, and output.

Evaluation of curriculum construction for translation majors. The level of major and curriculum construction is the fundamental embodiment of the might of application-oriented colleges and universities. First of all, the arrangement of major and curriculum of application-oriented undergraduate colleges and universities should adapt to the needs of regional economy and the development of enterprises and industries, and highlight the characteristics of application. Secondly, it is necessary to establish a team of professional teachers with dual-qualified teachers. Through college-enterprise cooperation, professional teachers can take the position in enterprises to train their practical ability. At the same time, enterprise translation experts are invited to help young teachers in colleges and universities understand the situation and needs of enterprises. Thirdly, it is important to highlight the practicality and characteristics of translation major construction, strengthen the practical teaching link, increase the proportion of practical teaching, and highlight the practicality in talent training program design and curriculum system construction.

Combination of process evaluation and result evaluation. Process-based evaluation, which pays attention to both process and result, is a trinity evaluation of learning motivation, process, and effect in the sense of curriculum implementation. This evaluation method can timely reflect students' learning situation and prompt students to actively reflect and summarize the learning process. Translation majors attach importance to the accumulation of translation practice, and process evaluation is an effective way of evaluation.

\section{Construction of the Quality Evaluation Index System for Application-Oriented Translation Talents}

The quality of talents cultivation is the key to the quality of higher education and the vitality of higher education. Currently, there are only two evaluation index systems in China, namely, undergraduate teaching evaluation index system and vocational college evaluation index system.

There is a lack of talent cultivation quality evaluation system for local application-oriented universities. Therefore, it is necessary to develop a talent cultivation quality evaluation index system for application-oriented universities, which can be constructed from four aspects: teacher team, major and curriculum construction, quality management, and teaching quality. Teachers team is evaluated by the government, school, and students from the aspects of student-teacher ratio, team structure, teachers' ethics level, teaching level and training. Major and curriculum development is evaluated by enterprises, schools, and governments from the aspects of major development, curriculum and teaching and practical teaching, with special emphasis on the integration between production and teaching to cultivate application-oriented translation talents. Quality management is evaluated by the government and schools in terms of teaching management teams and quality control. Teaching quality is comprehensively evaluated by the government, enterprises, colleges, and parents of graduates from the aspects of moral education, professional knowledge and ability, aesthetic education and physical education, in-school and out-school evaluation and employment. 
Table 1

Quality Evaluation Index System for Application-Oriented Translation Talents

\begin{tabular}{|c|c|c|c|}
\hline One class index & Evaluation subject & Two class index & Evaluation elements \\
\hline \multirow{5}{*}{ Teachers team } & \multirow{2}{*}{ Government } & \multirow{2}{*}{ Number \& structure } & Student-teacher ratio \\
\hline & & & Team structure \\
\hline & \multirow{2}{*}{ Student } & \multirow{2}{*}{ Teaching level } & Teachers' ethics level \\
\hline & & & Teaching level \\
\hline & College \& university & Training & Training \\
\hline \multirow{7}{*}{$\begin{array}{l}\text { Major and course } \\
\text { construction }\end{array}$} & \multirow{2}{*}{ Enterprise } & \multirow{2}{*}{ Major construction } & Major setup and structure adjustment \\
\hline & & & Cultivation program \\
\hline & \multirow{2}{*}{ College \& university } & \multirow{2}{*}{ Course and teaching } & Course content and course teaching resources \\
\hline & & & Classroom teaching and learning assessment \\
\hline & \multirow{3}{*}{$\begin{array}{l}\text { Government and } \\
\text { enterprise }\end{array}$} & \multirow{3}{*}{ Teaching practice } & Experimental teaching, teaching practice and internship \\
\hline & & & Social practice \\
\hline & & & Graduation thesis (design), comprehensive training \\
\hline \multirow{2}{*}{$\begin{array}{l}\text { Quality } \\
\text { management }\end{array}$} & Government & Teaching management team & Structure and quality \\
\hline & College \& university & Quality control & Rules and regulations \\
\hline \multirow{9}{*}{ Teaching quality } & \multirow{2}{*}{ Government } & \multirow{2}{*}{ Moral education } & Ideological and political education \\
\hline & & & Moral \\
\hline & \multirow{2}{*}{ Enterprise/graduate } & \multirow{2}{*}{ Expertise and ability } & Basic theories and skills in major \\
\hline & & & Professional ability \\
\hline & Government & $\begin{array}{l}\text { Physical education and } \\
\text { aesthetic education }\end{array}$ & Physical education and aesthetic education \\
\hline & \multirow{2}{*}{ College/enterprise } & \multirow{2}{*}{$\begin{array}{l}\text { On-campus and off-campus } \\
\text { evaluation }\end{array}$} & Teacher-student evaluation \\
\hline & & & Society evaluation \\
\hline & \multirow{2}{*}{ Parent/graduate } & \multirow{2}{*}{ Employment } & Employment rate \\
\hline & & & Employment quality \\
\hline
\end{tabular}

\section{Conclusion}

The construction of the quality evaluation system for translation talents is of great significance to improve the quality of translation talent cultivation. On the one hand, in the research of quality evaluation of application-oriented translation talent training, it is necessary to formulate quality evaluation standards for application-oriented translation talent training which are conducive to the sustainable development of the society toward "high quality". On the other hand, the quality evaluation system of translation talent cultivation needs the comprehensive evaluation of college-enterprise cooperation to objectively reflect the satisfaction of talent cultivation. Besides, construction of the quality evaluation index system for application-oriented translation talents will play an important role in promoting the cultivation of translation talents.

\section{References}

He, X. Y., \& Zhai, L. L. (2017). Construction of third-party evaluation index system for talent cultivation quality in colleges and universities. Journal of Harbin Institute of Technology, 38(10), 138-140.

Schaffner, C. (2012). Standardization and benchmark for improving translators training. Chinese Translators Journal, 6, 37-45.

Wang, M. D. (2018). Teaching quality management and evaluation mechanism of local undergraduate colleges under college-enterprise cooperation. Journal of Higher Education, 93(21), 143-146.

Wu, H. T., Liang, Y. C, Li, Y. P., \& Wang, Y. (2016). Exploration and practice of collaboration education modes in local undergraduate colleges and universities. Zhao Qing College Journal, 37(2), 52-58. 